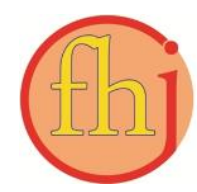

Faletehan Health Journal, 8 (2) (2021) 84-91

www. journal.Ippm-stikesfa.ac.id/ojs/index.php/FHJ

ISSN 2088-673X | e-ISSN 2597-8667

\title{
Terapi Komplementer Kombinasi Rendam Kaki Air Hangat dan Aromaterapi Lemon dalam Menurunkan Tekanan Darah
}

\author{
Siti Fadlilah ${ }^{1 *}$, Tia Amestiasih ${ }^{1}$, Bella Pebrianda ${ }^{1}$, Fransiska Lanni $^{1}$ \\ ${ }^{1}$ Program Studi Sarjana Keperawatan, Universitas Respati Yogyakarta \\ *Corresponding Author: sitifadlilah@respati.ac.id
}

\begin{abstract}
Abstrak
Kombinasi rendam kaki air hangat dan aromaterapi lemon memiliki efek relaksasi sehingga denyut jantung menjadi lebih tenang dan dapat mengontrol penurunan tekanan darah. Penelitian ini bertujuan mengetahui pengaruh kombinasi rendam kaki di air hangat dan aromaterapi lemon terhadap tekanan darah pada penderita prehipertensi di Puding Besar Kabupaten Bangka. Jenis penelitian adalah quasi-eksperimen dengan pre-post test control group design. Sampel yaitu 32 orang dengan tekanan darah kategori prehipertensi yang dipilih dengan teknik purposive sampling. Instrumen penelitian menggunakan tensimeter digital, standar operasional prosedur terapi dan pengukuran tekanan darah, serta lembar observasi. Analisis data menggunakan T-test paired dan T-test independent. Mean sistol pre-test dan post-test kelompok kontrol mengalami kenaikan sebanyak $3,42 \mathrm{mmHg}$. Mean diastol pre-test dan post-test kelompok kontrol mengalami penurunan $0,18 \mathrm{mmHg}$. Mean sistol dan diastol saat post-test dikurangi pre-test kelompok intervensi mengalami penurunan sebanyak $8,0 \mathrm{mmHg}$ dan $2,12 \mathrm{mmHg}$. Penurunan rata-rata tekanan darah sistolik dan diastolik pada kelompok intervensi lebih besar dibanding kelompok kontrol. Uji bivariat sistol kelompok kontrol dan intervensi yaitu $P$-value 0,041 dan 0,000 . Uji bivariat diastol kelompok kontrol dan intervensi yaitu $P$-value 0,929 dan 0,254 . Terapi kombinasi rendam kaki di air hangat dan aromaterapi lemon efektif dalam menurunkan tekanan darah sistolik pada pasien prehipertensi.
\end{abstract}

Kata Kunci: Aromaterapi, Prehipertensi, Rendam Kaki Air Hangat, Tekanan Darah

\section{Complementary Therapy of Warm Water Foot Soak and Lemon Aromatherapy Combination to Decrease Blood Pressure}

\begin{abstract}
Combination of warm water foot soak and lemon aromatherapy has a relaxing effect to make heart beat calmer and to control blood pressure decrease. This study aims to determine the effects of the combination of warm water foot soak and lemon aromatherapy on blood pressure of prehypertensive patients in Puding Besar, Bangka Regency. The research type is a quasi-experimental study with pre-post test control group design. The samples are 32 people with prehypertension category blood pressure, taken by purposive sampling technique. The research instruments used digital sphygmomanometer, standard operating procedures for therapy and blood pressure measurement, and observational sheets. The data analysis used paired T-test and independent $T$-test. The mean of systole in pre-test and post-test of the control group was increased by $3.42 \mathrm{mmHg}$. The mean of diastole in pre-test and post-test of the control group was decreased by $0.18 \mathrm{mmHg}$. The mean of systole and diastole of post-test and the pre-test in the intervention group was decreased by $8.0 \mathrm{mmHg}$ and $2.12 \mathrm{mmHg}$. The mean decrease of systolic and diastolic blood pressure in the intervention group was greater than the control group. The bivariate test for systole of the control and intervention group were $P$ values of 0.041 and 0.000 . The bivariate test for diastole of the control and intervention group were $P$-values of 0.929 and 0.254 . Combination therapy of warm water foot soak and lemon aromatherapy is effective to lower systolic blood pressure of prehypertensive patients.

Keywords: Aromatherapy, Prehypertension, Warm Water Foot Soak, Blood Pressure
\end{abstract}


Faletehan Health Journal, 8 (2) (2021) 84-91

\section{Pendahuluan}

Hipertensi diketahui sebagai silent killer, menjadi masalah kesehatan secara global. Hipertensi terjadi bila tekanan darah sistolik $>140$ $\mathrm{mmHg}$ dan tekanan darah diastolik $>90 \mathrm{mmHg}$ (LeMone., 2018). Data dari WHO (2013), menunjukkan kejadian hipertensi pada penduduk dewasa (> 25 tahun) di dunia sekitar $40 \%$. Prevalensi hipertensi pada dewasa tertinggi di Afrika (46\%) dan terendah di Amerika (35\%). Kejadian hipertensi lebih tinggi di negara berpendapatan rendah.

Menurut Kementerian Kesehatan \& Indonesia (2019), Hipertensi menjadi penyebab kematian nomor 4 di tahun 2014 (5,3\%). Prevalensi hipertensi pada usia 18 tahun sebesar $34,1 \%$, usia 31-44 tahun 31,6\%, usia 45-54 tahun 45,3\% dan usia 55-64 tahun sebesar 55,2\%. Prevalensi hipertensi tertinggi terjadi di Kalimantan Selatan sebesar 44,1\% dan terendah terjadi di Papua sebesar 22,2\%. Menurut Dinas Kesehatan Provinsi Kepulauan Bangka Belitung (2017), hipertensi di Bangka Belitung merupakan penyakit ke-2 terbanyak setelah ISPA. Angka hipertensi di Bangka Belitung sebanyak 58.789 orang. Hipertensi lebih banyak diderita oleh laki-laki dibandingkan perempuan. Prevalensi hipertensi tertinggi di Bangka Tengah (16.623 kasus) dan terendah di Belitung (3.303 kasus). Prevalensi hipertensi di Bangka sebanyak 4.841 kasus.

Hipertensi yang tidak ditangani akan berdampak pada masalah ekonomi dan sosial. Menurut Kementerian Kesehatan (2019), yang dikutip dari Sample Registration System (SRS) tahun 2014 sekitar 5,3\% penyebab kematian nomor 5 di Indonesia disebabkan oleh hipertensi dengan komplikasi yang terjadi pada semua umur. Hipertensi dapat menyebabkan aterosklerosis sehingga berisiko terjadinya penyakit jantung koroner dan stroke. Hipertensi juga dapat menyebabkan hipertrofi ventrikel sehingga dapat meningkatkan terjadinya distrimia dan gagal jantung. Selain menyebabkan perubahan pada sistem kardiovaskular hipertensi juga dapat mempengaruhi sistem saraf dan ginjal (LeMone $e t$ al., 2018).

Dalam mengatasi hipertensi dapat dilakukan dengan pengobatan farmakologi dan nonfarmakologi. Penatalaksanaan nonfarmakologi lebih dianjurkan karena tidak menyebabkan efek samping. Penatalaksanaan nonfarmakologi hipertensi melalui latihan fisik secara teratur, diet rendah lemak dan rendah garam atau diet Dietary Approaches to Stop Hypertension (DASH), yoga, meditasi dan dapat menggunakan terapi kombinasi rendam kaki air hangat dan aromaterapi (LeMone et al., 2018; Fadlilah et al., 2020). Rendam kaki air hangat mempunyai efektivitas dalam menurunkan tekanan darah karena air hangat dapat mempengaruhi sistem pembuluh darah dengan cara vasodilatasi dan dapat merileksasi otot-otot pada tubuh terutama pembuluh darah dan otot pada jantung sehingga dapat memperlancar aliran darah yang ada pada jantung (Ilkafah, 2016).

Sama halnya dengan rendam kaki air hangat, aromaterapi memiliki efektivitas dalam menurunkan tekanan darah. Aromaterapi bekerja melalui sistem sirkulasi dan sistem saraf olfaktori. Ketika aromaterapi dihirup melalui hidung, molekul aromaterapi memasuki membran rongga hidung dan mempengaruhi sistem saraf olfaktori. Saraf olfaktori menghantarkan impuls ke otak dan akan merangsang pengeluaran hormon endorfin yang berfungsi sebagai pengatur mood (Astuti \& Nugrahwati, 2018). Aromaterapi yang dihirupkan akan membuat tubuh menjadi tenang dan rileks sehingga pola pernapasan dan denyut jantung menjadi lebih tenang dan dapat mengontrol penurunan tekanan darah (Wulan \& Wafiyah, 2018). Menurut Wong (2010), aromaterapi lemon dapat mengatasi nyeri dan cemas, salah satu zat yang terkandung adalah linalool yang berfungsi untuk menstabilkan sistem saraf sehingga dapat menimbulkan efek yang tenang bagi orang yang menghirupnya (Rahmawati \& Rohmayanti, 2010).

Peningkatan tekanan darah harus dicegah secara dini. Kelompok prehipertensi mempunyai resiko untuk menjadi hipertensi di kemudian hari. Prehipertensi merupakan kondiai seseorang yang ditandai dengan kenaikan tekanan darah tetapi tidak cukup tinggi untuk dimasukkan dalam kategori hipertensi. Tekanan darah disebut prehipertensi apabila rentang di antara 120/80 $\mathrm{mmHg}$ dan 139/89 mmHg. Intervensi-intervensi non farmakologi dapat diterapkan untuk menjaga tekanan darah dalam kategori normal. Salah satu Intervensi yang diberikan adalah kombinasi rendam kaki di air hangat dan aromaterapi lemon. Menurut Kartika (2018), responden yang diberikan aromaterapi lemon mengatakan bahwa setelah diberikan aromaterapi lemon tidur menjadi lebih nyenyak dan lebih rileks, serta aromaterapi 
lemon lebih tinggi intensitasnya dalam menurunkan tekanan darah dibandingkan dengan aromaterapi lavender. Penelitian lain oleh Maisi (2017), menggunakan aromaterapi levender dan terapi musik efektif menurunkan tekanan darah pada ibu hamil dengan hipertensi. Penelitian Ilkafah (2016),membandingkan penggunaan obat antihipertensi dan terapi rendam air hangat. Hasil penelitian menunjukkan kedua terapi efektif menurunkan tekanan darah dan tidak ada perbedaan bermakna dalam menurunkan tekanan darah. Penelitian-penelitian sebelumnya memberikan satu intervensi pada kelompok intervensi yang bertujuan untuk menurunkan tekanan darah. Pada penelitian ini menggunakan kombinasi terapi non farmakologi pada kelompok intervensi untuk menurunkan tekanan darah.

Berdasarkan studi pendahuluan yang dilakukan pada 20 orang di Puding Besar Kabupaten Bangka didapatkan data usia 26-45 tahun, 2 orang hipertensi, 12 orang prahipertensi, dan 6 orang tekanan darah normal. Data tekanan darah minimal yaitu $107 / 71 \mathrm{mmHg}$, maksimal $170 / 114 \mathrm{mmHg}$, dan rata-rata $127,45 / 83,15$ mmHg. Hasil wawancara didapatkan 13 orang pernah melakukan pemeriksaan tekanan darah dan 7 orang belum pernah melakukan pemeriksaan tekanan darah. Mayoritas warga tidak melakukan upaya dan terapi apapun untuk menjaga tekanan darah. Penelitian ini bertujuan untuk mengetahui pengaruh pengaruh kombinasi rendam kaki di air hangat dan aromaterapi lemon terhadap tekanan darah pada penderita prahipertensi di Puding Besar Kabupaten Bangka.

\section{Metodologi Penelitian}

Jenis penelitian adalah penelitian quasieksperimen pretest and posttest control group design. Pengambilan data dilaksanakan di Desa Puding Besar Kecamatan Puding Besar Kabupaten Bangka pada 27 Mei-19 Juni 2020. Populasi terjangkau adalah masyarakat di Puding Besar Kabupaten Bangka. Sampel yaitu masyarakat di Puding Besar Kabupaten Bangka dengan prehipertensi yaitu mempunyai tekanan darah antara 120/80 mmHg dan 139/89 mmHg. Polupasi terjangkau sebanyak 257 orang. Sampel dipilih sesuai dengan kriteria inklusi dan kriteria eksklusi. Kriteria inklusi bersedia menjadi responden, perempuan, usia 26-45 tahun, IMT normal (18,525), tidak alergi lemon. Kriteria eksklusi yaitu mengkonsumsi alkohol, merokok, mengkonsumsi obat tekanan darah tinggi dan tekanan darah rendah, aktivitas fisik berat, dan diabetes melitus. Sampel dibagi menjadi kelompok kontrol dan kelompok intervensi. Sampel ditentukan dengan rumus $(\mathrm{t}-1)(\mathrm{r}-1) \geq 15$ dengan keterangan $\mathrm{t}=$ banyak kelompok perlakuan dan $\mathrm{r}=\mathrm{jumlah}$ replikasi. Hasil perhitungan sampel didapatkan jumlah sampel per kelompok sebanyak 16 responden. Untuk menghindari adanya drop out, ditambahkan $10 \%$ dari jumlah responden sehingga didapatkan jumlah sampel tiap kelompok sebanyak 18 orang. Pada saat penelitian terdapat satu orang dari masing-masing kelompok mengundurkan diri. Jumlah sampel akhir masing-masing kelompok sebanyak 17 responden sehingga total sabanyak 34 responden. Sampel diambil dengan Purposive sampling.

Pada kelompok intervensi mendapat terapi kombinasi rendam kaki air hangat dan aromaterapi, sedangkan kelompok kontrol tidak mendapatkan terapi apapun. Terapi rendam kaki air hangat diberikan selama 15 menit dengan suhu $39-40{ }^{\circ} \mathrm{C}$ diukur menggunakan termometer air dan ketinggian air $15 \mathrm{~cm}$ dari telapak kaki dan diukur menggunakan penggaris. Untuk menjaga kehangatan air, bagian atas baskom ditutup dengan handuk. Baskom yang digunakan berdiameter 30 $\mathrm{cm}$. Aromaterapi lemon diberikan dengan cara inhalasi, minyak esensial diberikan sebanyak 5 tetes dengan konsentrasi pure essential oil $100 \%$ dicampur ke dalam $20 \mathrm{ml}$ air hangat. Minyak esensial yang digunakan adalah lemon dan merek yang digunakan adalah natuna essential. Intervensi aromaterapi lemon diberikan pada jarak $2 \mathrm{~cm}$ dari responden dan Intervensi kombinasi rendam kaki air hangat dan aromaterapi lemon diberikan secara bersamaan selama 15 menit. Intervensi diberikan secara serentak pada hari dan waktu yang sama dan diberikan 1 kali pada sore hari selama 1 hari di dalam ruangan tertutup. Termometer air yang digunakan merupakan alat baru yang dilengkapi uji kalibrasi. Terapi kombinasi rendam kaki air hangat dan aromaterapi dilaksanakan sesuai dengan standar operasional prosedur. Penelitian dilakukan satu hari, satu kali intervensi untuk melihat efek langsung intervensi yang diberikan terhadap tekanan darah. Faktor yang mempengaruhi tekanan darah sangat bervariasi sehingga apabila intervensi diberikan secara serial dan kelemahan peneliti dalam mengendalikan variabel perancu maka ada banyak bias yang akan muncul. Terapi yang diberikan bersifat mempengaruhi saraf simpatis 
Faletehan Health Journal, 8 (2) (2021) 84-91 www. journal.Ippm-stikesfa.ac.id/ojs/index.php/FHJ ISSN 2088-673X | 2597-8667

dan hormonal, dimana kedua sistem ini mempunyai cara kerja yang cepat dalam menurunkan tekanan darah.

Tekanan darah terbagi menjadi 2 yaitu sistolik dan diastolik. Tekanan darah diukur pada lengan kanan bagian atas dan dalam posisi duduk, sebelum dilakukan pengukuran tekanan darah responden dianjurkan untuk istirahat selama 5 menit. Pada saat pretest tekanan darah diukur 5 menit sebelum diberikan intervensi dan posttest dilakukan pengukuran tekanan darah setelah 2 menit diberikan intervensi. Intervensi yang diberikan adalah kombinasi rendam kaki air hangat dan aromaterapi lemon. Tekanan darah diukur menggunakan tensimeter digital yang telah diuji kalibrasi. Pengukuran tekanan darah dilakukan sesuai dengan standar operasional prosedur. Data tekanan darah direkap di lembar observasi. Uji normalitas data menggunakan Shaprio-Wilk karena jumlah sampel $<50$ orang. Hasil uji nomalitas menunjukkan p-value 0,57> 0,05 yang berarti normal. Uji bivariat yang digunakan yaitu uji $T$ Test Independent. Selanjutnya untuk menguji perbedaan pada penelitian ini yaitu menggunakan uji Paired T-Test. Penelitian dilakukan setelah mendapatkan ethical clearance dari Komisi Etik Penelitian Kesehatan Fakultas Ilmu Kesehatan Universitas Respati Yogyakarta nomor 140.3/FIKES/PL/V/2020 dan surat ijin penelitian nomor 934.2/FIKES/PL/V/2020.

\section{Hasil dan Pembahasan}

Tabel 1: Gambaran Usia Responden pada Kelompok Kontrol dan Intervensi di Puding Besar Kabupaten Bangka ( $\mathrm{n}=17$ )

\begin{tabular}{|c|c|c|c|c|c|}
\hline $\begin{array}{c}\text { Usia } \\
\text { responden }\end{array}$ & $\sum$ & Min & Max & Mean & SD \\
\hline $\begin{array}{l}\text { Kelompok } \\
\text { Kontrol }\end{array}$ & 17 & 26 & 45 & 34,88 & 6,353 \\
\hline $\begin{array}{l}\text { Kelompok } \\
\text { Intervensi }\end{array}$ & 17 & 30 & 44 & 36,47 & 4,652 \\
\hline
\end{tabular}

Tabel 1 diketahui usia minimal pada kelompok kontrol yaitu 26 tahun, maksimal 45 tahun, rata-rata 34,88 tahun, dan standar deviasi 6,353 . Hasil usia minimal pada kelompok intervensi yaitu 30 tahun, maksimal 44 tahun, ratarata 36,47 tahun, dan standar deviasi 4,652.

Tabel 2: Hasil Tekanan Darah pada Kelompok Kontrol di Puding Besar Kabupaten Bangka

\begin{tabular}{cccccc}
\hline \multirow{2}{*}{$\begin{array}{c}\text { Kelompok } \\
\text { Kontrol }\end{array}$} & \multicolumn{5}{c}{ Tekanan Darah $(\mathbf{m m H g})$} \\
\cline { 2 - 6 } & $\boldsymbol{\Sigma}$ & Min & Max & Mean & SD \\
\hline Pretest & & & & & \\
Sistolik & 17 & 115 & 162 & 133,76 & 1,389 \\
Diastolik & 17 & 77 & 116 & 87,94 & 1,315 \\
\hline Posttest & & & & & \\
Sistolik & 17 & 114 & 163 & 137,18 & 1,844 \\
Diastolik & 17 & 75 & 108 & 87,76 & 1,580 \\
\hline
\end{tabular}

Tabel 2 diketahui mean tekanan darah pretest sistolik dan diastolik pada kelompok kontrol yaitu 133,76 mmHg dan 87,94 mmHg. Mean tekanan darah posttest sistolik dan diastolik pada kelompok kontrol yaitu $137,18 \mathrm{mmHg}$ dan $87,76 \mathrm{mmHg}$.

Tabel 3: Hasil Tekanan Darah pada Kelompok Intervensi di Puding Besar Kabupaten Bangka

\begin{tabular}{lccccc}
\hline \multirow{2}{*}{$\begin{array}{l}\text { Kelompok } \\
\text { Intervensi }\end{array}$} & \multicolumn{5}{c}{ Tekanan Darah (mmHg) } \\
\cline { 2 - 6 } & $\boldsymbol{\Sigma}$ & Min & Max & Mean & SD \\
\hline Pretest & & & & & \\
$\quad$ Sistolik & 17 & 115 & 162 & 136,18 & 11,881 \\
Diastolik & 17 & 71 & 110 & 88,12 & 9,089 \\
\hline Posttest & & & & & \\
Sistolik & 17 & 108 & 151 & 128,18 & 11,518 \\
Diastolik & 17 & 69 & 111 & 86,00 & 10,753 \\
\hline
\end{tabular}

Tabel 3 diketahui mean tekanan darah pretest sistolik dan diastolik pada kelompok intervensi yaitu $136,18 \mathrm{mmHg}$ dan $87,72 \mathrm{mmHg}$. Mean tekanan darah posttest sistolik dan diastolik kelompok intervensi yaitu $128,18 \mathrm{mmHg}$ dan 86,00 $\mathrm{mmHg}$.

Tabel 4: Perubahan Tekanan Darah Sistolik dan Diastolik pada Kelompok Kontrol dan Intervensi

\begin{tabular}{|c|c|c|c|c|}
\hline Kelompok & $\sum$ & Mean & $\begin{array}{l}\text { Selisih } \\
\text { Mean }\end{array}$ & $\begin{array}{c}P \\
\text { value }\end{array}$ \\
\hline \multicolumn{5}{|l|}{ Kontrol } \\
\hline $\begin{array}{l}\text { Pretest Sistolik } \\
\text { Posttest } \text { Sistolik }\end{array}$ & 17 & $\begin{array}{l}133,76 \\
137,18\end{array}$ & 3,412 & 0,041 \\
\hline \multicolumn{5}{|l|}{ Kontrol } \\
\hline $\begin{array}{l}\text { Pretest Diastolik } \\
\text { Posttest Diastolik }\end{array}$ & 17 & $\begin{array}{l}87,94 \\
87,76 \\
\end{array}$ & $-0,176$ & 0,929 \\
\hline \multicolumn{5}{|l|}{ Intervensi } \\
\hline $\begin{array}{l}\text { Pretest } \text { Sistolik } \\
\text { Posttest } \text { Sistolik }\end{array}$ & 17 & $\begin{array}{l}136,18 \\
128,18 \\
\end{array}$ & $-8,000$ & 0,000 \\
\hline \multicolumn{5}{|l|}{ Intervensi } \\
\hline $\begin{array}{l}\text { Pretest Diastolik } \\
\text { Posttest Diastolik }\end{array}$ & 17 & $\begin{array}{l}88,12 \\
86,00 \\
\end{array}$ & $-2,118$ & 0,254 \\
\hline
\end{tabular}


Faletehan Health Journal, 8 (2) (2021) 84-91

www. journal.Ippm-stikesfa.ac.id/ojs/index.php/FHJ

ISSN 2088-673X | 2597-8667

Tabel 4 diketahui selisih mean tekanan darah sistolik pretest dan posttest pada kelompok kontrol yaitu 3,412 $\mathrm{mmHg}$ (peningkatan tekanan darah sistolik). Hasil analisis bivariat didapatkan $p$-value $0,041 \mathrm{mmHg}(\mathrm{P}<0,05)$, artinya ada perbedaan dari tekanan darah sistolik pretest dan posttest. Selisih mean tekanan darah diastolik pretest dan posttest kelompok kontrol yaitu $-0,176 \mathrm{mmHg}$ (penurunan tekanan darah diastolik). Hasil analisis bivariat didapatkan $p$-value $0,929 \mathrm{mmHg}(\mathrm{P}>0,05)$, artinya tidak ada perbedaan dari tekanan darah diastolik pretest dan posttest. Tabel 4 juga diketahui selisih mean sistolik pretest dan posttest pada kelompok kontrol yaitu $-9,000 \mathrm{mmHg}$ (penurunan tekanan darah sitolik). Hasil analisis bivariat didapatkan $p$ value $0,000 \mathrm{mmHg}(\mathrm{P}<0,05)$, artinya ada pengaruh kombinasi rendam kaki di air hangat dan aromaterapi lemon terhadap tekanan darah sistolik pada prehipertensi. Selisih mean tekanan darah diastolik pretest dan posttest pada kelompok intervensi yaitu $-2,118 \mathrm{mmHg}$ (penurunan tekanan darah diastolik). Hasil analisis bivariat didapatkan p-value $0,254 \mathrm{mmHg}(\mathrm{P}>0,05)$ yang menyatakan tidak ada pengaruh kombinasi rendam kaki di air hangat dan aromaterapi lemon terhadap tekanan darah diastolik pada prehipertensi.

Tabel 5: Perbandingan Tekanan Darah Sistolik dan Diastolik Posttest Kelompok Kontrol dan Kelompok Intervensi

\begin{tabular}{lcccc}
\hline \multicolumn{1}{c}{ Kelompok } & $\sum$ & Mean & $\begin{array}{c}\text { Selisih } \\
\text { Mean }\end{array}$ & $\begin{array}{c}\boldsymbol{P} \\
\text { value }\end{array}$ \\
\hline Kontrol Posttest Sistolik & 17 & 137,18 & $-9,000$ & 0,049 \\
Intervensi Posttest Sistolik & 17 & 128,18 & & \\
\hline Kontrol Posttest Diastolik & 17 & 87,76 & & \\
Intervensi Posttest & 17 & 86,00 & $-1,765$ & 0,602 \\
Diastolik & & & & \\
\hline
\end{tabular}

Tabel 5 menunjukkan selisih mean tekanan darah sistolik posttest pada kelompok kontrol dan intervensi yaitu $-9,000 \mathrm{mmHg}$. Hasil negatif menunjukkan bahwa mean tekanan darah sistolik posttest kelompok intervensi lebih rendah dibandingkan kelompok kontrol. Hasil analisis bivariat tekanan darah sistolik posttest kelompok kontrol dan kelompok intervensi didapatkan $p$ value $0,049 \mathrm{mmHg}$, artinya ada perbedaan yang bermakna dari tekanan darah sistolik posttest kelompok kontrol dan posttest intervensi. Selisih mean tekanan darah diastolik posttest kelompok kontrol dan intervensi yaitu-1,765 mmHg. Hasil negatif menunjukkan bahwa mean tekanan darah diastolik posttest kelompok intervensi lebih rendah dibandingkan kelompok kontrol. Hasil analisis bivariat tekanan darah diastolik posttest kelompok kontrol dan intervensi didapatkan p-value 0,602 $\mathrm{mmHg}$, artinya tidak ada perbedaan yang bermakna dari tekanan darah diastolik posttest kelompok kontrol dan posttest intervensi.

Berdasarkan tabel 2 dan tabel 3 diketahui ratarata tekanan darah sistolik dan diastolik kelompok kontrol dan intervensi menunjukkan kategori prehipertensi (tekanan darah sistolik 120-139 $\mathrm{mmHg}$ dan diastolik 80-89 $\mathrm{mmHg}$ ) dan standar deviasi lebih kecil dari nilai mean yang menunjukkan data tekanan darah kurang bervariasi. Tekanan darah terbagi menjadi dua yaitu tekanan darah sistolik dan tekanan diastolik. Tekanan darah sistolik adalah tekanan maksimal yang dihasilkan saat jantung berkontraksi sedangkan tekanan darah diastolik merupakan tekanan yang dihasilkan saat terjadinya relaksasi ventrikel dan pengisian jantung kembali. Klasifikasi tekanan darah dibagi menjadi 4 bagian yaitu tekanan darah normal (sitol $<120 \mathrm{mmHg}$, diastolik $<80 \mathrm{mmHg}$, prahipertensi (sistolik 120$139 \mathrm{mmHg}$, diastolik 80-89 $\mathrm{mmHg}$ ), hipertensi derajat $1(140-159 \mathrm{mmHg})$, dan hipertensi derajat 2 ( sistolik >160 mmHg, diatol >100 $\mathrm{mmHg}$ ) (JNC, 2003; Lewis et al., 2007; Smeltzer et al., 2009). Tekanan darah pretest pada penelitian merupakan sebagai pembanding pengukuran tekanan darah setelah diberikan terapi kombinasi rendam kaki di air hangat dan aromaterapi lemon sehingga dapat mengetahui apakah terapi yang diberikan memiliki pengaruh dalam menurunkan tekanan darah.

Pada tabel 4 menyatakan ada perbedaan yang signifikan pada tekanan darah sistolik pretest dan posttest pada kelompok kontrol. Dari hasil selisih mean dapat dinyatakan adanya perubahan yang negatif karena tekanan darah tersebut mengalami peningkatan saat posttest. Hal ini berbeda dengan penelitian yang dilakukan oleh Juwariah (2015), bahwa tidak ada perbedaan hasil tekanan darah sistolik pretest dan posttest kelompok kontrol. Perbedaan tekanan darah pada kelompok kontrol yang tidak diberikan intervensi dapat disebabkan karena adanya faktor kebisingan antara responden yang saling bercerita serta lokasi rumah tempat dikumpulnya responden berada dekat dengan jalan raya sehingga faktor kebisingan sulit untuk dihindari. Kebisingan yang terjadi dianggap sebagai ancaman oleh otak dan mempengaruhi pengeluaran hormon stres seperti katekolamin yang disekresi oleh medula kelenjar adrenal dan 
Faletehan Health Journal, 8 (2) (2021) 84-91

neurotransmitter. Stres yang terjadi akan mempengaruhi tekanan darah menjadi meningkat (Ardiansyah et al., 2013). Berdasarkan hasil penelitian ini menyatakan berarti tidak ada perbedaan yang bermakna terhadap tekanan darah sistolik pretest dan posttest pada kelompok kontrol. Menurut Lani (2001) di dalam Panggalih et al., 2015), tekanan darah sistolik mengalami perubahan sesuai dengan kegiatan yang dilakukan sedangkan tekanan darah diastolik relatif tidak berubah-ubah. Hal ini sejalan dengan penelitian Juwariah (2015), bahwa tidak ada perbedaan tekanan darah diastolik pretest dan posttest.

Berdasarkan hasil penelitian menunjukkan terdapat pengaruh kombinasi rendam kaki di air hangat dan aromaterapi lemon terhadap tekanan darah sistolik pada prahipertensi. Selisih rata-rata tekanan darah sebelum dan sesudah diberikan terapi kombinasi rendam kaki di air hangat dan aromaterapi lemon adalah $-8,000 \mathrm{mmHg}$ yang menyatakan adanya perubahan yang signifikan dan positif pada terapi kombinasi yang dilakukan berupa penurunan tekanan darah. Penelitian ini sejalan dengan penelitian yang dilakukan oleh Wulan \& Wafiyah (2018), bahwa ada perubahan yang signifikan sebelum dan sesudah diberikan aromaterapi. Sama halnya dengan penelitian Werdyastri et al., (2014), pemberian aromaterapi lemon efektif dalam menurunkan tekanan darah sistolik sebesar $6,36 \%$. Pemberian aromaterapi akan memberikan stimulus pada saraf olfaktori di hidung dan impus tersebut akan diteruskan pada sistem limbik yang terdapat pada otak. Ambiglada dan hipokampus adalah bagian di sistem limbik yang berfungsi untuk memproses aroma. Amiglada mempunyai fungsi untuk memerintahkan dalam merespon emosi dan hipokampus berfungsi untuk eksplisit memori. Hubungan dari kedua fungsi tersebut mengkoneksi otak untuk mengontrol detak jantung, tekanan darah, pernapasan, level stress, dan hormone (Snyder \& Linquist, 2010).

Selain dengan aromaterapi lemon dalam penelitian penurunan tekanan darah dipengaruhi oleh rendam kaki di air hangat. Sejalan dengan penelitian yang dilakukan oleh Ilkafah (2016), bahwa ada perubahan setelah diberikan rendam kaki air hangat karena ada proses perpindahan suhu air hangat ke tubuh sehingga menjadikan pembuluh darah mengalami vasodilatasi dan menurunkan ketegangan pada otot sehingga aliran darah dalam tubuh menjadi lancar. Terapi air hangat dapat merespon fisiologis yang bersifat terapeutik dengan cara membuang kelebihan panas dan dapat menurunkan tekanan darah serta dapat melenturkan jaringan otot ikat, melenturkan struktur otot, mengatasi rasa nyeri dan dapat mendilatasi pembuluh darah yang mempengaruhi fungsi jantung serta paru-paru (Hayes \& Hall, 2015; Ilkafah, 2016; Setyoadi \& Kushariyadi, 2011; Solechah et al., 2017).

Hasil selisih mean tekanan darah diastolik pretest dan posttest pada kelompok intervensi yaitu $-2,118 \mathrm{mmHg}$ dan $P$-value $0,254(\mathrm{P}>0,05)$. Hasil p-value menunjukkan tidak ada pengaruh kombinasi rendam kaki di air hangat dan aromaterapi lemon terhadap tekanan darah diastolik pada prahipertensi. Selisih rata-rata 2,118 $\mathrm{mmHg}$ menunjukkan adanya penurunan tekanan darah. Hal ini sejalan dengan penelitian yang dilakukan oleh Wulan \& Wafiyah (2018), bahwa tidak terdapat perubahan tekanan darah diastolik sebelum dan setelah diberikan aromaterapi pada pasien hipertensi. Dalam penelitian Anggraeni, (2017), bahwa aromaterapi tidak efektif dalam menurunkan hipertensi dalam kehamilan. Hasil tekanan darah diastolik yang tidak berpengaruh setelah diberikan kombinasi rendam kaki di air hangat dan aromaterapi lemon bertentangan dengan teori. Dalam teori aromaterapi dapat menurunkan tekanan darah, karena molekul aromaterapi yang dihirup dapat mengimpuls sistem limbik pada otak kemudian dapat mempengaruhi detak jantung dan tekanan darah serta rendam kaki di air hangat memiliki proses perpindahan suhu air hangat ke tubuh dan menjadikan pembulah darah mengalami vasodilatasi dan menurunkan ketegangan pada otot kemudian aliran darah dalam tubuh menjadi lancer (Ilkafah, 2016; Snyder \& Linquist, 2010).

Berdasarkan tabel 5 selisih rata-rata tekanan darah rata-rata sistolik posttest kelompok kontrol dan intervensi yaitu $-9,000 \mathrm{mmHg}$ dan $P$-value 0,049 . Hasil yang didapatkan menyatakan bahwa terdapat perbedaan yang bermakna antara tekanan darah sistolik kelompok kontrol dengan kelompok intervensi rendam kaki di air hangat dan aromaterapi lemon. Selisih $-9,000 \mathrm{mmHg}$ artiny pada kelompok intervensi mean tekanan darah sistolik lebih rendah sebanyak $9,00 \mathrm{mmHg}$ dibandingkan kelompok kontrol. Hal ini dikarenakan pada posttest sistolik kelompok kontrol terdapat kenaikan tekanan darah sedangkan posttest sistolik kelompok intervensi memiliki perubahan penurunan tekanan darah. Adanya 
perbandingan yang signifikan antara kelompok kontrol dan intervensi karena pada kelompok intervensi keadaan tubuh menjadi lebih rileks oleh faktor aromaterapi lemon dan rendam kaki di air hangat. Efektivitas dari rendam kaki di air hangat dapat memperlancar sirkulasi darah dan dapat menguatkan otot-otot dan ligamen. Aromaterapi lemon memiliki efektivitas dalam menurunkan tekanan darah karena aromaterapi lemon mengandung linalool dan dapat membuat tubuh menjadi rileks, tenang, dan menimbulkan rasa mengantuk ingin tidur. Ketika tubuh dalam keadaan rileks akan menghasilkan hormon endorfin sehingga tekanan darah dapat menurun (Saputra, Juniawan, \& Putra, 2018; Setyoadi \& Kushariyadi, 2011). Berdasarkan tabel 5 juga menunjukkan hasil yang didapatkan menyatakan bahwa tidak terdapat perbandingan yang bermakna antara tekanan darah diastolik posttest kontrol dengan posttest intervensi kombinasi rendam kaki di air hangat dan aromaterapi lemon. Menurut Lani (2001) di dalam Panggalih et al., (2015), tekanan darah sistolik mengalami perubahan sesuai dengan kegiatan yang dilakukan sedangkan tekanan darah diastolik relatif tidak berubah-ubah.

Hasil penelitian menunjukkan terapi komplementer melalui kombinasi rendam kaki di air hangat dan aromaterapi lemon efektif menurunkan tekanan darah pada prahipertensi. Selain dikombinasikan dengan aromaterapi lemon, rendam kaki di air hangat juga dapat dikombinasikan dengan progresive muscle relaxation sebagai terapi untuk menurunkan tekanan darah. Hasil penelitian Fadlilah et al., (2020), menunjukkan terapi merendam kaki dengan air hangat dan relaksasi otot progresif berguna untuk menurunkan tekanan darah. Terapi non farmakologi lebih murah, mudah, dan aman sehingga dapat dipraktikan pada penderita prahipertensi atau hipertensi sehari-hari.

\section{Simpulan}

Hasil penelitian menunjukkan terapi kombinasi rendam kaki di air hangat dan aromaterapi lemon efektif menurunkan tekanan darah pada prehipertensi. Pada kelompok kontrol terdapat kenaikan tekanan darah posttest dibandingkan pretest. Kelompok intervensi menunjukkan penurunan rata-rata tekanan darah sistolik dan diastolik. Terapi kombinasi rendam kaki di air hangat dan aromaterapi lemon dapat dijadikan salah satu pilihan sebagai alternatif manajemen non farmakologi pada penderita peningkatan tekanan darah.

\section{Referensi}

Anggraeni, Y., Estuning, R. D., \& Asiyah, S. (2017). Efektivitas Metode Inhalasi Aromaterapi (Campuran Minyak Esensial Lavender Dan Neroli) Untuk Menurunkan Hipertensi Dalam Kehamilan. 2(2), 132-137. https://doi.org/ISSN 2503-5088

Ardiansyah, M. R., Salim, J., \& Susihono, W. (2013). Pengaruh Intensitas Kebisingan Terhadap Tekanan Darah dan Tingkat Stres Kerja. Jurnal Teknik Industri, 1(1), 7-12.

Astuti, R., \& Nugrahwati, F. (2018). Intervention Using Rose Aromatherapy to Lowering Blood Pressure of Elderly with Hypertension. International Journal of Scientific and Technology Research, 7(4), 246-250.

Dinas Kesehatan Provinsi Kepulauan Bangka Belitung. (2017). Profil Kesehatan Provinsi Kepulauan Bangka Belitung.

Fadlilah, et al. (2020). Soak Feet with Warm Water and Progressive Muscle Relaxation Therapy on Blood Pressure in Hypertension Elderly. $P$ J M H S, 14(3), 1444-1448.

Fadlilah, S., Adi, S., \& Mohamad, J. (2020). Cucumber (Cucumis Sativus) and Tomato (Solanum Lucopersicium) Juice Effective to Reduce Blood Pressure. GCS Biological and Pharmaceutical Sciences, 10(1), 01-08.

Hayes, K. W., \& Hall, K. D. (2015). Agens Modalitas Untuk Praktik Fisioterapi Edisi 6. Jakarta: EGC.

Ilkafah, I. (2016). Perbedaan Penurunan Tekanan Darah Lansia dengan Obat Anti Hipertensi dan Terapi Rendam Air Hangat di Wilayah Kerja Puskesmas Antara Tamalanrea Makassar. PHARMACONJurnal Ilmiah Farmasi-UNSRAT, 5(2), 228-235.

JNC. (2003). The Seventh Report of the Joint National Committee on Prevention, Detection, Evaluation, and Treathment of Hight Blood Pressure. USA: U. S. Departmen of Health and Human Service.

Juwariah, T. (2015). Pengaruh Aromaterapi Lavender terhadap Kualitas Tidur dan Tekanan Darah Lansia di Panti Sosial Tresna Wherda Tulungagung 2015. Jurnal Kesehatan Ibu Dan Anak, 1(1), 60-70.

Kartika, U. Y. (2018). Perbandingan Aromaterapi Lemon dan Aromaterapi Lavender terhadap 
Faletehan Health Journal, 8 (2) (2021) 84-91

Perubahan Tekanan Darah pada Penderita Hipertensi di Wilayah Kerja UPK Puskesmas Khatulistiwa Pontanak.

Kementerian Kesehatan, \& Indonesia, R. (2019). Hipertensi Penyakit Paling Banyak Diidap Masyarakat. https://doi.org/351.077 Ind r

LeMone, P., Burke, K. M., \& Bauldoff, G. (2018). Buku Ajar Keperawatan Medikal Bedah. Jakarta: EGC.

Lewis, S. L., Heitkemper, M. M., Dirksen, S. R., O'Brien, P. G., \& Bucher, L. (2007). Medical Surgical-Nursing Assessment and Management of Clinical Problems Seventh Edition. China: Elsevier.

Maisi, S., Suryono, Widyawati, M. N., Suwondo, A., \& Kusworowulan, S. (2017). Effectiveness of Lavender Aromatherapy and Classical Music Therapy in Lowering Blood Pressure in Pregnant Women With Hypertension. Belitung Nursing Journal, 3(6), 750-756. https://doi.org/10.33546/bnj.301

Panggalih, M. H. S. T., Hardiyanti, M., \& Sani, F. I. (2015). Perbedaan Perubahan Tekanan Darah dan Denyut Jantung pada Berbagai Intensitas Latihan Atlet Balap Sepeda. Jurnal Keolahragaan, 3(2), 218-227.

Rahmawati, I., \& Rohmayanti. (2010). Efektivitas Aromaterapi Lavender dan Aromaterapi Lemon terhadap Intensitas Nyeri Post Sectio Caesarea (SC) di Rumah Sakit Budi Rahayu Kota Magelang. 10-16.

Saputra, R. R., Juniawan, H., \& Putra, F. (2018). Perbandingan antara Pemberian Aromaterapi Kenanga dan Aromaterapi Lemon Terhadap Penurunan Tekanan Darah di RSUD Tanah Bumbu. 9(2), 521-533.

Setyoadi, S., \& Kushariyadi. (2011). Terapi Modalitas Keperawatan pada Klien Psikogeriatrik. Jakarta: Salemba Medika.

Smeltzer, S. C., Bare, B. G., Hinkle, J. L., \& Cheever, K. H. (2009). Brunner \& Suddarth's Textbook of Medical-Surgical Nursing.

Snyder, M., \& Linquist, R. (2010). Complementary \& Alternative Therapies in Nursing Sixth Edition. New York: Springer Publishing Company.

Solechah, N., Maisi, G. N. M., \& Rottie, J. V. (2017). Pengaruh Terapi Rendam Kaki Dengan Air Hangat Terhadap Penurunan Tekanan Darah Pada Pasien Dengan Hipertensi di Puskesmas Bahu Manado. Jurnal Keperawatan, 5(1).
Werdyastri, A., Armiyati, Y., \& Kusuma, M. A. B. (2014). Perbedaan Efektifitas Aromaterapi Lemon dan Relaksasi Nafas Dalam terhadap Penurunan Tekanan Darah pada Pasien Hipertensi di RSUD Tugurejo Semarang. Jurnal Ilmu Keperawatan Dan Kebidanan, 111.

WHO. (2013). A Global Brief on Hypertension: Silent Killer, Global Public Health Crisis. https://doi.org/10.5005/ijopmr-24-1-2

Wulan, E. S., \& Wafiyah, N. (2018). Perubahan Tekanan Darah Sebelum dan Sesudah Pemberian Aromaterapi pada Pasien Hipertensi di Wilayah Kerja Puskesmas Jati Kabupaten Kudus. Jurnal Keperawatan Dan Kesehatan Masyarakat, 7(1), 10-19. https://doi.org/10.1017/CBO9781107415324. 004 